\title{
Pulmonary, microbiological and hematological changes in Crotalus durissus terrificus (Serpentes, Viperidae) parasitized by nematodes of the genus Rhabdias (Nematoda, Rhabdiasidae)
}

\author{
[Alterações Pulmonares, microbiológicas e hematológicas em Crotalus durissus terrificus (Serpentes, Viperidae) \\ parasitadas pelos nematódeos do gênero Rhabdias (Nematoda, Rhabdiasidae)] \\ K.R. Santos ${ }^{1}$, R.K. Takahira ${ }^{2}$, V.L.M. Rall ${ }^{3}$, C. Calderón ${ }^{1}$, J.L. Sequeira ${ }^{2}$, R.J. Silva ${ }^{3 *}$ \\ ${ }^{1}$ Aluno de pós-graduação - FMVZ-UNESP - Botucatu, SP \\ ${ }^{2}$ Faculdade de Medicina Veterinária e Zootecnia - UNESP - Botucatu, SP \\ ${ }^{3}$ Instituto de Biociências - UNESP - Botucatu, SP \\ Distrito de Rubião Júnior \\ 18618-000 - Botucatu, SP
}

\begin{abstract}
This study reported the pulmonary, microbiological, and hematological alterations in Crotalus durissus terrificus parasitized by nematodes of the genus Rhabdias. Histological, microbiological, and hematological analysis were performed on parasitized $(n=6)$ and non-parasitized $(n=6)$ snakes. Granulocytic and mononuclear cell infiltrates in the pulmonary parenchyma and epithelium were also observed during the histological analysis of parasitized snakes. Microbiological analysis of parasitized animals revealed the following Gram-negative bacteria: Citrobacter divergens, Burkholderia cepacia, Stenotrophomonas maltophilia, Proteus vulgaris, Enterobacter sakazakii, Enterobacter ammnigenus, Pseudomonas aeruginosa, Pantoea sp. and Providencia rettgeri. In non-parasitized snakes, the following species were identified: B. cepacia, Pseudomonas fluorescens, and Acinetobacter baumanii. Increased levels of plasmatic protein, decreased lymphocyte counts, and normal red blood cell values were observed in parasitized animals.
\end{abstract}

Keywords: snake, Crotalus durissus terrificus, Rhabdias spp., histopathology, microbiology, hematology

\section{RESUMO}

Este trabalho relata as alterações pulmonares, microbiológicas e hematológicas em Crotalus durissus terrificus parasitadas pelo nematódeo do gênero Rhabdias. As análises histológicas, microbiológicas e hematológicas foram realizadas em serpentes parasitadas $(n=6)$ e não parasitadas $(n=6)$. Foram observados infiltrados de células granulocíticas e mononucleares no parênquima pulmonar durante a análise histopatológica das serpentes parasitadas. A análise microbiológica revelou as seguintes bactérias Gram-negativas; Citrobacter divergens, Burkholderia cepacia, Stenotrophomonas maltophilia, Proteus vulgaris, Enterobacter sakazakii, Enterobacter ammnigenus, Pseudomonas aeruginosa, Pantoea sp. e Providencia rettgeri. Nas serpentes não parasitadas foram identificadas: B. cepacia, Pseudomonas fluorescens e Acinetobacter baumanii. Nos animais parasitados observaram-se: aumento da concentração de proteína plasmática, diminuição da contagem de linfócitos, e valores normais de hematimetria.

Palavras-chave: serpente, Crotalus durissus terrificus, Rhabdias spp., histopatologia, microbiologia, hematologia

Recebido em 28 de agosto de 2007

Aceito em 13 de março de 2008

* Autor para correspondência (corresponding author)

E-mail: reinaldo@ibb.unesp.br 


\section{INTRODUCTION}

Several species of amphibians and reptiles can be parasitized by rhabdiasid nematodes (Yamaguti, 1961). Nematodes of the genus Rhabdias have been found in the lungs of several species of Brazilian snakes (Vicente et al., 1993; Araújo et al., 1999; Silva et al., 2001) and high infection rates with these nematodes have been reported in Crotalus durissus terrificus. Silva et al. (2001) studied the frequency of nematodes in $24 C$. $d$. terrificus specimens and found infection rate of $70.8 \%$ with pulmonary nematodes.

Rhabdiasid nematodes inhabit the snake lungs and can affect the state of health of these animals. It has been reported that Rhabdias spp. can cause a "verminous" pneumonia, characterized by a gaping mouth, wheezing, and exudates from the trachea (Klingenberg, 1993; Mader, 1996).

However, studies on the effects of the parasitism of those helminths on the snake respiratory system are rare. The objective of this investigation was to report the pulmonary, microbiological, and hematological alterations in C. $d$. terrificus parasitized by nematodes of the genus Rhabdias.

\section{MATERIAL AND METHODS}

This study was performed from March 2003 to February $2005^{1}$. Fecal samples of recently captured adult $C$. d. terrificus snakes from the Botucatu region, State of São Paulo, Brazil, were analyzed by fecal flotation test (Hoffman, 1987) and 12 snakes were grouped as parasitized $(n=6)$ and non-parasitized $(\mathrm{n}=6)$ by rhabdiasid nematodes.

The snakes were euthanised with thiopental sodium $^{2}$ given intramuscularly. Lungs were collected for histological and microbiological analyses and blood was collected for hematological examination.

For histological evaluation, lungs samples were preserved in $10 \%$ formalin and then embedded in

\footnotetext{
${ }^{1}$ This study was approved by the Ethics Commission (53/2002-CEEA) of the Universidade Estadual Paulista, Botucatu, SP

${ }^{2}$ Thiopentax ${ }^{\circledR}$, Cristália - Itapira, SP, Brazil.
}

historesin (2-hydroxyethyl methacrylate) and $4 \mu \mathrm{m}$ sections were stained with hematoxylineosin and examined with a computerized system for image analyses ${ }^{3}$. The morphology of the lungs and cell counts were evaluated using these slides. The cell counts were performed within ten $0.3 \mathrm{~mm}^{2}$ areas, observed at a magnification of 400x.

Microbiological examinations were performed with other lung fragments, which were collected, put in tubes with Brain-Heart Infusion broth $(\mathrm{BHI})^{4}$, and incubated at $30^{\circ} \mathrm{C}$ for 24 hours. After incubation, samples of broth were plated onto media selective for Pseudomonas (cetrimid), Aeromonas (starch ampicillin agar) ${ }^{3}$, and Gramnegative enteric bacilli (xylose lysine deoxycholate agar and McConkey agar), and were incubated at $30^{\circ} \mathrm{C}$ for 24 hours. After this period, the typical colonies were transferred to tubes containing tryptic soy agar (TSA), and incubated under the same conditions. The strains were tested for oxidase production and seeded in triple sugar iron agar (TSI) ${ }^{3}$ before incubating at $30^{\circ} \mathrm{C}$ for 24 hours. After the preliminary biochemical results, the isolates were identified using the API $20 \mathrm{kit}^{5}$ for identification of Enterobacteriaceae or the API $20 \mathrm{NE}$ kit for identification of non-fermenting Gram-negative bacilli.

Blood $(0.5 \mathrm{ml})$ was directly collected from the vena cava immediately after euthanasia in 3\% ethylene diaminetetra-acetic acid (EDTA) anticoagulant solution. The complete blood cell counts were performed in a Neubauer chamber using $0.01 \%$ toludine blue in saline solution. The correction for thrombocytes was based on a differential cell count of 200 cells. Hemoglobin levels were determined by the cyanmethemoglobin method by centrifuging the cyanmethemglobin reagent-blood mixture for three minutes and measuring spectrophotometrically (Jain, 1993; Feldman et al., 2000; Raskin, 2000). The packed cell volume was determined by the microhematocrit method, centrifuging microhematocrit tubes at $12,000 \mathrm{xg}$ for five minutes. The differential leuckocyte counts were performed on blood smears stained

\footnotetext{
${ }^{3}$ Lite Qwin 2.5, Leica Microsystems - Wetzlar, Germany.

${ }^{4}$ OXOID - São Paulo, Brazil.

${ }^{5}$ Biomérieux - Marcy l'Etoile, France.
} 
by Giemsa. Total plasma protein levels were measured using an Atago refractometer (Jain, 1986).

Erythrocytic data from the parasitized and nonparasitized animals were compared by the Student $t$ test. Leucogram data were analyzed by the MannWhitney non-parametric test. Statistical significance was set at 5\%. All statistical analyses were carried out using the SigmaStat 2.0 software (Jandel Corporation).

\section{RESULTS}

The histological evaluation of parasitized snake lungs showed the presence of granulocytic and mononuclear infiltrates. These alterations were also observed in some non-parasitized animals, but at a lower level (Fig. 1). The medians of granulocytic cell counts of the parasitized and non-parasitized snake lungs were 14.8 and 0.95 , respectively $(\mathrm{P}<0.05)$ (Fig. 2).
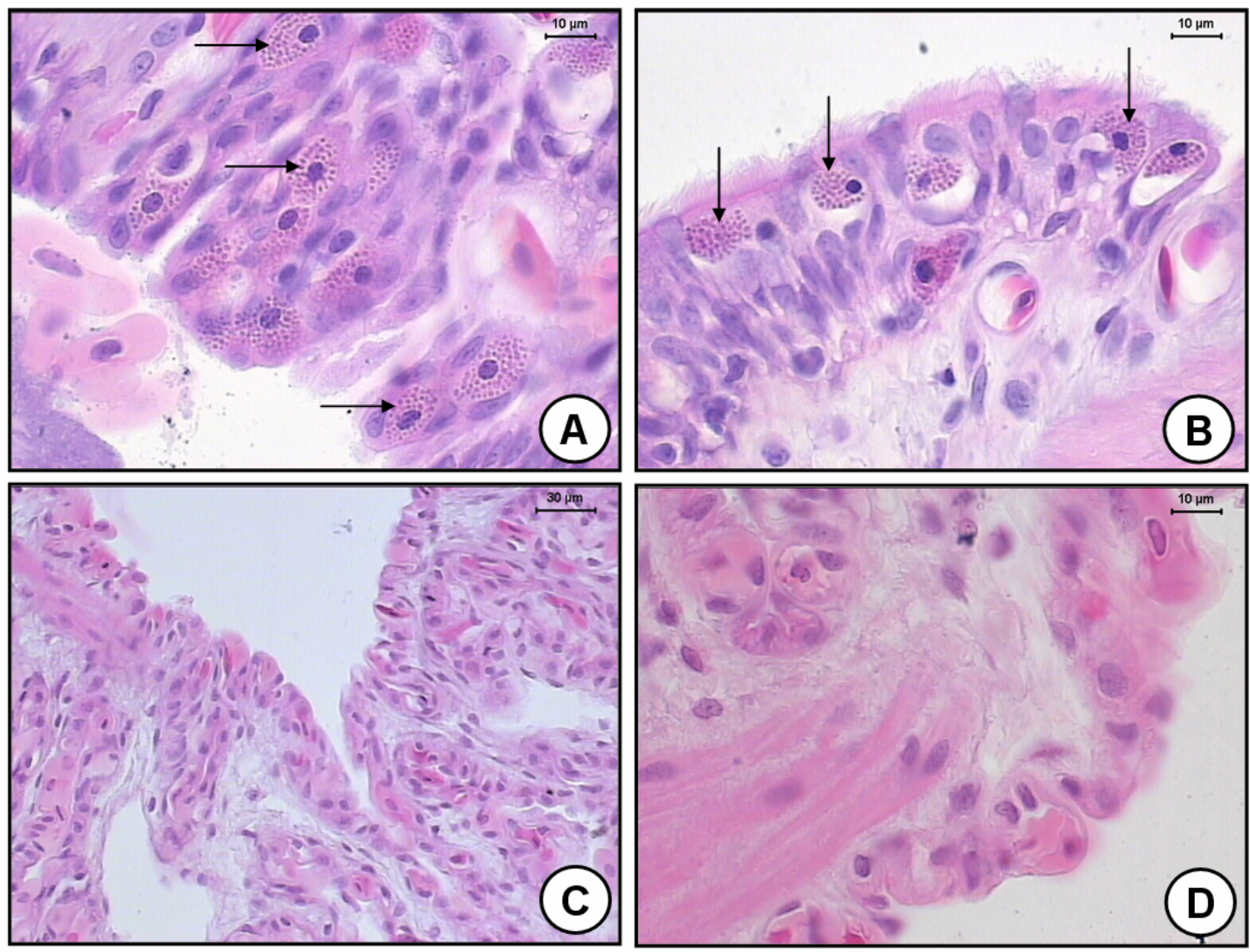

Figure 1. Histopathology of Crotalus durissus terrificus lung. (A-B) Parasitized by nematodes of the genus Rhabdias; pulmonary parenchyma and epithelium showing a large amount of granulocytic cell infiltrates (arrows). (C-D) Pulmonary parenchyma and epithelium from a non-parasitized animal. HE. (A, B, and D, magnification of 1000x; C, magnification of $400 x)$. 


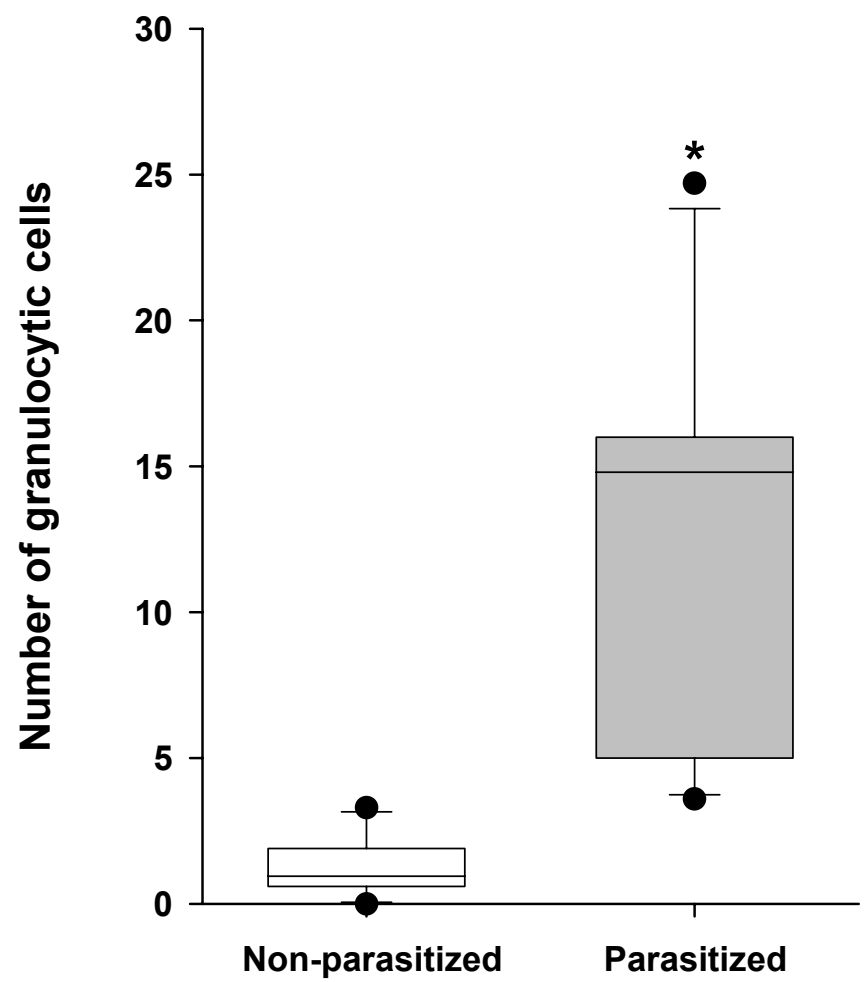

Figure 2. Distribution of the medians of granulocytic cell counts in histological sections of Crotalus durissus terrificus lungs parasitized $(\mathrm{n}=6)$ and non-parasitized $(\mathrm{n}=6)$ by nematodes of the genus Rhabdias. Each boxplot represents $25-75$ percentile values, with the median as an internal line; the error bars represent the 10 and 90 percentiles; the circles represent the outliers. $* \mathrm{P}<0.05$.

Table 1. Bacteria identified in the lungs of Crotalus durissus terrificus, parasitized ( $\mathrm{n}=6$ ) and nonparasitized $(\mathrm{n}=6)$ by nematodes of the genus Rhabdias

\begin{tabular}{clcl}
\hline Snake & \multicolumn{1}{c}{ Parasitized } & Snake & \multicolumn{1}{c}{ Non-parasitized } \\
\hline 2 & Citrobacter divergens & 1 & Acinetobacter baumanii \\
& $\begin{array}{l}\text { Burkholderia cepacia } \\
\text { Stenotrophomonas maltophilia }\end{array}$ & 3 & Negative \\
7 & Negative & 4 & Negative \\
8 & Proteus vulgaris & 5 & Negative \\
9 & Enterobacter sakazakii & & \\
& $\begin{array}{l}\text { Enterobacter amnigenus } \\
\text { Pantoea } \text { sp. }\end{array}$ & 6 & Burkholderia cepacia \\
10 & $\begin{array}{l}\text { Pseudomonas aeruginosa } \\
\text { Pantoea } \text { sp. }\end{array}$ & 12 & Pseudomonas fluorescens \\
& Providencia rettgeri & Negative
\end{tabular}


Pulmonary, microbiological and hematological...

Table 2. Erythrogram findings in the lungs of Crotalus durissus terrificus parasitized $(\mathrm{n}=6)$ and non-parasitized $(\mathrm{n}=6)$ by nematodes of the genus Rhabdias

\begin{tabular}{cccccccc}
\hline Animal & $\begin{array}{c}\text { Erythrocyte } \\
(\mathrm{N} / \mu \mathrm{l})\end{array}$ & $\begin{array}{c}\text { Thrombocyte } \\
(\mathrm{N} / \mu \mathrm{l})\end{array}$ & $\begin{array}{c}\text { Hemoglobin } \\
(\mathrm{g} / \mathrm{dl})\end{array}$ & $\begin{array}{c}\text { PCV } \\
(\%)\end{array}$ & $\begin{array}{c}\text { Plasma } \\
\text { proteins }(\mathrm{g} / \mathrm{dl})\end{array}$ & $\begin{array}{c}\text { MCV } \\
(\mathrm{Fl})\end{array}$ & $\begin{array}{c}\text { MCHC } \\
(\%)\end{array}$ \\
\hline Non-parasitized & & & & & & & \\
1 & & & & & & & \\
3 & 625,000 & 12,269 & 9.5 & 34 & 3.0 & 548 & 27.9 \\
4 & 565,000 & 13,938 & 8.3 & 29 & 3.8 & 518 & 28.6 \\
5 & 552,500 & 12,640 & 10 & 32 & 3.2 & 582 & 31.3 \\
6 & 400,000 & 15,000 & 8.3 & 27 & 3.2 & 675 & 30.7 \\
12 & 355,000 & 10,634 & 7.4 & 29 & 4.4 & 816 & 25.8 \\
Mean & 525,000 & 13,920 & 9.5 & 27 & 4.4 & 514 & 35.2 \\
SD & 503,750 & 13,066 & 8.8 & 30 & 3.7 & 608 & 30.0 \\
\hline Parasitized & 104,088 & 1,547 & 0.9 & 2.8 & 0.6 & 117 & 3.2 \\
2 & & & & & & & \\
7 & 485,000 & 4,331 & 8.5 & 32 & 4.3 & 687 & 26.1 \\
8 & 475,000 & 17,750 & 7.6 & 26 & 4.6 & 547 & 29.2 \\
9 & 375,000 & 4,187 & 6.4 & 21 & 4.6 & 560 & 30.4 \\
10 & 475,000 & 9,056 & 8.5 & 30 & 4.8 & 631 & 28.3 \\
11 & 352,500 & 17,250 & 7.9 & 26 & 4.6 & 738 & 30.3 \\
\hline Mean & 320,000 & 17,000 & 8.3 & 22 & 4.2 & 687 & 37.7 \\
SD & 413,750 & 11,596 & 7.8 & 26 & 4.5 & 641 & 30.0 \\
\hline
\end{tabular}

PCV: packed cell volume; MCV: mean corpuscular volume; MCHC: mean corpuscular hemoglobin concentration; SD: standard deviation.

Table 3. Leucogram findings in the lungs of Crotalus durissus terrificus parasitized $(\mathrm{n}=6)$ and non-parasitized $(\mathrm{n}=6)$ by nematodes of the genus Rhabdias

\begin{tabular}{|c|c|c|c|c|c|c|c|}
\hline Animal & $\begin{array}{c}\text { Leukocyte } \\
N / \mu l\end{array}$ & $\begin{array}{c}\text { Lymphocyte } \\
\mathrm{N} / \mu 1\end{array}$ & $\begin{array}{c}\text { Monocyte } \\
N / \mu l\end{array}$ & $\begin{array}{c}\text { Heterophil } \\
\mathrm{N} / \mu \mathrm{l}\end{array}$ & $\begin{array}{c}\text { Basophil } \\
\mathrm{N} / \mu \mathrm{l}\end{array}$ & $\begin{array}{c}\text { Eosinophil } \\
\mathrm{N} / \mu \mathrm{l}\end{array}$ & $\begin{array}{c}\text { Azurophil } \\
N / \mu l\end{array}$ \\
\hline \multicolumn{8}{|c|}{ Non-parasitized } \\
\hline 1 & 6,606 & $1,981.8$ & 66.1 & $3,038.8$ & 462.4 & 132.1 & 924.8 \\
\hline 3 & 8,186 & $5,730.0$ & 81.9 & 818.6 & 491.2 & 409.3 & 654 \\
\hline 4 & 7,110 & $4,450.4$ & 142.2 & $1,493.1$ & 284.4 & 142.2 & 497.7 \\
\hline 5 & 3,750 & $2,437.5$ & 300.0 & 187.5 & 262.5 & 262.5 & 300 \\
\hline 6 & 11,992 & $8,633.7$ & 239.9 & $2,038.5$ & 0 & 120.0 & 959.3 \\
\hline 12 & 10,080 & $4,637.0$ & 504.0 & 806 & 0 & 0 & $4,133.0$ \\
\hline Median & 7,648 & $4,543.7$ & 191 & $1,155.9$ & 273.4 & 137.1 & 789.8 \\
\hline SIQR & 1,737 & $1,646.5$ & 109.5 & 616.3 & 231.2 & 71.3 & 230.8 \\
\hline \multicolumn{8}{|l|}{ Parasitized } \\
\hline 2 & 3,150 & 913.5 & 0 & $1,228.52$ & 0 & 220.5 & 787.5 \\
\hline 7 & 9,053 & $3,892.6$ & 0 & $1,720.0$ & 0 & 271.6 & 3168.4 \\
\hline 8 & 12,563 & 879.3 & $1,381.9$ & $8,416.8$ & 0 & 376.8 & 1507.5 \\
\hline 9 & 3,351 & $1,105.8$ & 0 & $1,340.3$ & 0 & 0 & 904.7 \\
\hline 10 & 4,485 & 897.0 & 0 & $1,524.9$ & 179.4 & 0 & 1883.7 \\
\hline 11 & 3,230 & 871.1 & 323 & 775.2 & 0 & 0 & 1550.4 \\
\hline Median & 3,918 & 905.3 & 0 & $1,432.6$ & 0 & 110.2 & $1,528.9$ \\
\hline SIQR & 2,912 & 113.3 & 161.5 & 246.0 & 0 & 135.8 & 489.5 \\
\hline
\end{tabular}

SIQR: semi-interquartile range 


\section{DISCUSSION}

Histological analyses of the parasitized snakes showed an infiltrate of granulocytic and mononuclear cells in the lungs. These alterations were also observed in non-parasitized snakes, but at a lower level. Data regarding the histopathology of lungs of snakes parasitized by rhabdiasid nematodes are rare. Samora (1993) reported acute parasitic enteritis caused by Rabdias vellardi in Bothrops moojeni. Kolesnikovas (1997) noted that 53\% of C. d. terrificus infected by $R$. vellardi presented pneumonia; while Klingenberg (2000) reported that verminous pneumonia in snakes is characterized by mouth opening, breathing difficulty, and exudate expulsion via trachea. Similar results were observed in the present study; however, there have been no reports, to date, on the presence of granulocytic and mononuclear cell infiltrates in association with Rhabdias spp. Infection. Although, such histological findings were observed by Tucunduva et al. (2001) in an experimental study of inflammation in the subcutaneous tissue of Boa constrictor constrictor.

Microbiological evaluations showed that $83 \%$ of the parasitized snakes presented bacterial growth. In contrast, for the non-parasitized snakes, this percentage was $33 \%$. The number of bacterial species found in parasitized snakes was higher than the non-parasitized species (nine versus three). These data suggest an association between the infection by rhabdiasid nematodes and bacterial occurrence, and indicate that rhabdiasid nematode larvae can carry soil microorganisms to internal organs of their hosts.

Rhabdiasid nematodes have a direct life cycle with a free-living generation and a parasitic phase. The eggs deposited in the lungs by the parthenogenetic females pass through the respiratory system, are swallowed and then eliminated in the feces of the host. Larvae hatch and first, second, and third-stage larvae develop in the external environment. Infective larvae penetrate the skin and migrate to the lungs where they become mature and produce eggs (Anderson, 2000).

First and second-stage larvae ingest microorganisms and organic material in the external environment (Cheng, 1986) and then, when they penetrate their hosts, they can contaminate them. The present study supports this hypothesis. The major observation in this respect was the occurrence of bacteria of the genus Pantoea in the lungs of snakes infected with rabdiasid nematodes. The Pantoea is a Gram-negative bacillus frequently isolated from soil, water, plants, seeds, animals, and humans (Manulis and Barash, 2003). Animal and human infections by Pantoea spp. occur in debilitated individuals; however, these bacteria are more frequently isolated from soil and plants (Asis and Adachi, 2003; Manulis and Barash, 2003). The finding of Pantoea sp. in the lungs of snakes infected with Rhabdias spp. reinforces the hypothesis that rhabdiasid larvae can carry soil microorganisms to internal organs of their hosts.

There are a number of reports on the microbiota of snakes. However, few of these related $C . d$. terrificus. Moreno et al. (1973) isolated Citrobacter sp. (35\%), Proteus vulgaris (16.4\%), Morganella morgani (=Proteus morgani) (14.4\%), and Providencia rettgeri (=Proteus rettgeri) (13\%) from feces of this host species. However, no data regarding lungs microbiota are available for $C$. $d$. terrificus. Thus, the data of the present study contribute to the knowledge of the microbiota in this species.

Klingenberg (1993) reported that rhabdiasid nematodes can cause a "verminous" pneumonia in snakes that is characterized by a gaping mouth, wheezing, and exudate from trachea. Conversely, Marcus (1981) reported few, or the absence of clinical signs in snakes infected with $R$. vellardi. Pneumonia in snakes was described in the presence of Aeromonas hydrophila (Marcus, 1971). Hilf et al. (1990) isolated Proteus vulgaris in snakes from the Boidae family and found pneumonia in two animals that died. These data show that the pneumonia was associated with lungs bacterial infection. Thus, it is suggested that the "verminous" pneumonia reported by Klingenberg (1993) may be caused or worsened by the microorganisms that affect the lungs. In the case of Rhabdias spp., pneumonia may be caused by soil microorganisms carried to the lungs.

Some bacteria identified in this study (Table 1) have been previously described as causing pneumonia in snakes. Hilf et al. (1990) found $P$. rettgeri in the lungs of Boidae snakes and 
demonstrated that in animals with pneumonia, the number of Gram-negative bacilli was significantly higher than in normal animals. In the same study, two snakes that died as a consequence of pneumonia were necropsied and the lungs were analyzed. The microbiological analyses of the first snake revealed that its lungs presented a high infection by $A$. hydrophila and, in the second snake, Salmonella sp., Citrobacter sp., and Enterococcus sp. were identified.

In the hematological examinations, few alterations were detected when parasitized and non-parasitized snakes were compared. Plasma protein levels and lymphocyte counts were the only variables that presented statistically significant differences. Plasma protein levels were increased in parasitized snakes in relation to non-parasitized snakes; however, according to Feldman et al. (2000) and Raskin (2000), animals from both groups presented normal levels. The observed values from hematological examinations were also similar to only one hematological study carried out with Bothrops leucurus in Brazil (Grego et al., 2006).

Parasitized animals also presented a lymphopenia in comparison to non-parasitized animals. This alteration is frequently associated with a nutritional deficiency or secondary diseases due to stress or immunosuppression (Campbell, 2004) or to some parasitic infections (Feldman et al., 2000). Thus, the observed lymphopenia may be associated with the presence of Rhabdias spp. in the parasitized animals.

The erythrocyte counts were also decreased in the parasitized and in two non-parasitized animals, suggesting an anemia (Raskin, 2000); however, mean corpuscular volume and mean corpuscular hemoglobin concentration showed similar values in the parasitized and nonparasitized groups and they were similar to the results found by Grego et al. (2006). Two parasitized animals (10 and 11) and one nonparasitized (12) presented azurophilia, indicating an antigenic stimulation and infectious diseases (Feldman et al., 2000; Grego et al., 2006).

Therefore, it is suggested that the presence of Rhabdias spp. may be loosely associated with alterations in the hematological parameters of the host. However, the hematological data from the reptiles should be analyzed with caution since external factors, such as environmental variations, may inhibit or intensify the response of the animal to a disease (Feldman et al., 2000; Campbell, 2004).

The present study showed that $C$. $d$. terrificus snakes parasitized by nematodes of the genus Rhabdias present granulocytic and mononuclear cell infiltrates in their lungs, a high diversity of microbiota, and few hematological alterations. Thus, this nematode may be considered as a significant health problem in snakes and sanitary handling must be employed when such animals are introduced into captivity.

\section{ACKNOWLEDGEMENTS}

The authors wish to thank the Fundação para o Desenvolvimento da UNESP (FUNDUNESP) and the Coordenadoria de Aperfeiçoamento de Pessoal de Nível Superior (CAPES) for the grants to K. R. dos Santos.

\section{REFERENCES}

$\begin{array}{llr}\text { ANDERSON, R.C. Nematode parasites of } \\ \text { vertebrates: } & \text { Their development and } \\ \text { transmission. } & \text { 2.ed. Wallingford: CABI } \\ \text { Publishing, 2000. 672p. } & \end{array}$

ARAÚJO, T.; MORO, L.; LÚCIA, M. et al. Ocorrência de alguns endo e ectoparasitos no serpentário da UNIFENAS, Universidade de Alfenas, MG. Braz. J. Vet. Res. Anim. Sci., v.36, p.19-22, 1999.

ASIS, C.A.; ADACHI, K. Isolation of endophytic diazotroph Pantoea agglomerans and nondiazotroph Enterobacter asburiae from sweetpotato stem in Japan. Lett. Appl. Microbiol., v.38, p.19-23, 2003.

CAMPBELL, T.W. Hematology of reptiles. In: THRALL, M.A. (Ed). Veterinary hematology and clinical chemistry. Baltimore: Lippincott Williams \& Wilkins, 2004. p.259-276.

CHENG, T.C. General parasitology. 2.ed. Orlando: Academic, 1986. 827p.

FELDMAN, B.F.; ZINKL, J.G.; JAIN, N.C. Schalm's veterinary hematology. 5.ed. 
Philadelphia: Lippincott Willians \& Wilkins, 2000. 1344p.

GREGO, K.F.; ALVES, J.A.S.; RAMEH DE ALBUQUERQUE, L.C. et al. Referências hematológicas para jararaca de rabo branco (Bothrops leucurus) recém-capturadas da natureza. Arq. Bras. Med. Vet. Zootec., v.58, p.1240-1243, 2006.

HILF, M.; WAGNER, R.A.; YU, V.L. A prospective study of upper airway flora in healthy boid snakes and snakes with pneumonia. J. Zoo Wildl. Med., v.21, p.318-325, 1990.

HOFFMANN, R.P. Diagnóstico de parasitismo veterinário. Porto Alegre: Sulina, 1987. p.33-39.

JAIN, N.C. Schalm's veterinary hematology. Philadelphia: Lea \& Febiger, 1986. 1221p.

JAIN, N.C. Essentials of veterinary hematology. Philadelphia: Lea \& Febiger, 1993. 417p.

KLINGENBERG, R.J. Understanding reptiles parasites. California: Advanced Vivarium Systems, 1993. 83p.

KLINGENBERG, R.J. Reptilian parasite testing. In: FUDEGE, A.M. (Ed). Laboratory medicine avian and exotic pets. Philadelphia: W.B. Saunders, 2000. p.486.

KOLESNIKOVAS, C.K.M. Patologia comparada de cascavéis (Crotalus durissus terrificus, Laurenti, 1768) mantidos em cativeiro. São Paulo: 1997. 53f. Dissertação (Mestrado) Faculdade de Medicina Veterinária e Zootecnia, Universidade de São Paulo, São Paulo.

MADER, D.R. Reptile medicine and surgery. Philadelphia: W.B. Saunders, 1996. p.11261132.

MANULIS, S.; BARASH. I. Pantoea agglomerans pvs. Gypsophilae and betae recently evolved pathogens? Mol. Plant. Pathol., v.4, p.307-314, 2003.

MARCUS, L.C. Infectious diseases of reptiles. $J$. Am. Vet. Med. Assoc., v.159, p.1626-1631, 1971.

MARCUS, L.C. Veterinary biology and medicine of captive amphibians and reptiles. Philadelphia: Lea \& Febiger, 1981. p.114-174.

MORENO, G.; LOPES, A.M.; BELLUOMINI, E. et al. Enterobactérias isoladas de anfíbios e répteis. Rev. Inst. Med. Trop. São Paulo, v.15, p.122-126, 1973.

RASKIN, E.R. Repitilian complete blood count. In: FUDGE, A.M. (Ed). Laboratory medicine avian and exotic pets. Philadelphia: W.B. Saunders, 2000. p.486.

SAMORA, C.C.C. Acute parasitic enteritis in Bothrops moojeni Hoge, 1965 snakes (Viperidae, Crotalinae). Snake, v.25, p.131-134, 1993.

SILVA, R.J.; BARRELLA, T.H.; NOGUEIRA, M.F. et al. Frequency of helminths in Crotalus durissus terrificus (Serpentes, Viperidae) in captivity. Rev. Bras. Parasitol. Vet., v.10, p.9193, 2001.

TUCUNDUVA, M.; BORELLI, P.; SILVA, J.R.M.C. Experimental study of induced inflammation in the Brazilian boa (Boa constrictor constrictor). J. Comp. Pathol., v.125, p.174-181, 2001.

VICENTE, J.J.; RODRIGUES, H.O.; GOMES, D.C. et al. Nematóides do Brasil. Parte III: Nematóides de répteis. Rev. Bras. Zool., v.10, p.19-168, 1993.

YAMAGUTI, S. Systema Helminthum Nematodes. Vol. III. - Part I and II. London: Interscience Publishers, 1961. 1261p. 